\section{Impact of Quantitative Easing on Purchased Asset Yields, its Persistency and Overlap'}

\begin{abstract}
The main focus of this paper rests on the event study and SVAR analysis of quantitative easing that was initiated as a reaction to the financial crisis at the turn of 2008/2009 that finally ended in 2014. The Fed was virtually unable to continue with its conventional monetary policy regime in environment of zero-bound threshold, where there is no easy way to decrease main monetary policy rate any further. As a reaction to this limitation, the Fed started to practice quantitative easing and other unconventional measures. Event study examines changes in yields of purchased assets, namely US Treasuries, MBS and agency debt, and on two-day event window of the OIS and yield spreads quantifies imminent impact of QE announcements and relevant chairman speeches. Following VAR model and impulse-response functions, I examine the impact of QE and its persistency on purchased asset and on alternative asset classes in the framework of various transmission channels such as signalling, portfolio-balancing and liquidity channels. In this study I found non-negligible impact of QE on purchased assets in both models through all waves of QE and time persistency patterns in IRFs part. Furthermore, some evidence for portfolio-balancing channel and other related channels was found.
\end{abstract}

Keywords: monetary policy, quantitative easing, credit easing

JEL classification: E520, E580, E440

1 This article is a part of the research funded by the University of Economics, Prague, under the project IGS F1/5/2014 Finanční a hospodářský cyklus.
${ }^{*}$ Department of Monetary

Theory and Policy, University of

Economics, Prague

Email:

jakljakub@email.cz 


\section{Introduction}

As a reaction to the Great Recession, the Fed started to take unconventional monetary-policy countermeasures and, after several decreases of the federal fund rate (FFR) during 2008, reached the effective bottom of this rate. In this band $0-0.25 \%$, the Fed reached zero-bound which represents the frontier of conventional monetary policy of setting FFR (see Bernanke (2009)). The circumstance forced the Fed to implement unconventional measures in the form of quantitative easing $(\mathrm{QE})$ and forward guidance $(\mathrm{FG})^{2}$. The Fed was followed by the Bank of Japan, which started a certain form of QE already in 2001, and then by the Bank of England, the ECB and others as well - for details of measures taken across the central banks see Klyuev, Imuset \& Srinivasan (2009).

During the three waves of QE, the Fed purchased mortgage-backed securities (MBS), treasury securities (TS) and agency bonds (AB) of Government-Sponsored Enterprises (GSEs) ${ }^{3}$ in its effort to ease deterioration in the MBS market and lower yields of purchased assets in order to transfer yield decline to other markets and indirectly lower the costs of long term investments of firms and individuals.

There are several effects that form theoretical ground of QE and are related to specific channels - signalling channel, portfolio-rebalancing channel, liquidity channel and other more or less important channels that altogether can make QE policy valid in unconventional times of zero bound. Frequently mentioned portfolio-rebalancing channel, for instance, can be working when decrease in yield of one asset in a pool of available investment assets lowers the rate of required yields in other assets considered by investors during their investment decisions making. Signalling channel can influence expected path of future FFR etc. Moreover, important is an increase in non-borrowed reserves (NBR) of commercial banks in the Fed caused by QE purchase program itself. This fact eases conditions on interbank money market and can foster issuance of cheaper loans and mediate economic growth and bring the Fed nearer to its goals in the form of maximum employment, stable prices and moderate long-term interest rates - see Bernanke, Reinhart \& Sack (2004).

\footnotetext{
"Forward guidance is communication about the likely future course of monetary policy and, in addition, the FOMC used forward guidance language about the flow-based asset purchase program." See The Board of Governors of the Fed.

3 Fannie Mae, Freddie Mac, and Ginnie Mae
} 
This study uses event-study method to examine the immediate impact of the Fed's QE announcements on USD denominated TS, MBS and AB yields and its effect on commercial investment substitutes - corporate bonds and equity indices. Event study analysis is based on the spread between overnight indexed swap (OIS) and TS yield change spread. Structural vector autoregression (SVAR) model analysis follows and together with impulse-response functions (IRFs) quantifies the impact and persistence of $\mathrm{QE}$ announcements on yields. The main focus of this study is to identify possible channels of QE transmission and to quantify impact and persistence of QE on yields of purchased asset with overlap to commercial assets by event-study and IRFs and to provide the connection with existing theoretical concepts of considered transmission mechanisms and existing studies. Brief QE related events description and both methods follow in the next sections.

\section{Transmission mechanism of QE}

The conventional monetary policy has become ineffective in the zero-bound environment and the Fed was forced to choose an alternative way that would be effective even under this condition. The Fed decided to implement QE and FG (sometimes called "open-mouth operations"). ${ }^{4}$ During the exercising of conventional monetary policy with providing liquidity via repo operations and influencing the level of NBR by outright OMO operations, the goal of the Fed is usually only to temporarily influence the level of NBR and not to affect prices or yields of purchased assets. This is the main difference compared to QE, when the Fed contrariwise wants to affect price and yields of purchased assets and consequently prices and yields of other assets in the economy - therefore the purchases have to be great in numbers. These operations are not sterilized in SOMA (System Open Market Account) portfolio and there is eventually no decrease in NBR as there is in case of conventional operations redeemed by counter operation when the objective of such an operation is not the adjustment of the level of liquidity provided in order to satisfy commercial bank needs or currency in circulation demands. Proclaimed nature of QE by Bernanke et al. (2004) is a reduction of risk and term premiums for long term IRs. Working mechanism described by theoretical studies is not unified and a variety of possible transmission channels of $\mathrm{QE}$ is presented.

4 For other possible unconventional measures effective in zero-bound environment see Yates (2003). 
In the framework of New Keynesian economics (NKE) and Ricardian equivalence, the effectiveness of QE is inseparably connected with its ability to affect expectations of economic agents regarding expected future path of FFR or inflation. It is, in fact, the signal channel where the Fed signals its devotion to hold FFR low even for the time period that is longer than adequate according to the Taylors rule, and this channel is examined for instance in Eggertsson and Woodford (2003) or Clouse, Dale, Athanasios, Small \& Tinsley (2003). The Fed did both simultaneously implemented FG, which is explicit form of communication about future FFR, and initiated QE purchases that are credible evidence of its intention to adhere to proclaimed lower FFR for long period. This, together with increasing inflation expectations that are raised from QE itself, leads to a decrease of future expected real market IR and works as a strong QE channel especially in a deeply indebted economy such as the U.S. economy.

NKE extended for financial frictions or incomplete markets and imperfect substitutability of purchased assets can also cover asset prices channel when the QE causes the price changes by influencing the relative supply of purchases assets and consequent yield changes as well. Vayanos and Vila (2009) came with preferred habitat model where interaction amongst preferred-habitat investors and riskaverse arbitrageurs determine bond prices within NKE framework and found theoretical support for QE in a fact that shock to bond supply affects bond prices especially in long duration segment. Andrés, López-Salido \& Nelson (2004) presented a similar model of imperfect asset substitution between money and long-term bond holdings of some households. Therefore, a necessary condition is preferred habitat or market segmentation when the perfect arbitrage between short-term and long-term TS is ruled out. Under these conditions, the Fed can impact the prices on the affected markets as describes Mishkin (2010).

The majority of studies, e.g. D’Amico and King (2010), Hamilton and Wu (2011) and Gagnon, Raskin, Remache \& Sack (2011), mention portfolio balance channel formally described by Tobin (1969) and studied by Brunner and Meltzer (1973) and Friedman and Schwartz, as a subset of asset price channel, when relative changes of nominal asset prices with respect to prices of other assets that are being considered as an investment alternative are the cause of portfolio rebalancing process. QE simply increases the prices of purchased assets and lowers their yields and drain purchased investment securities from the market as well. These purchased securities are no longer available for private investors and their relative scarcity compared to securities that are not the subject of QE purchases is boosted. Investors consequently optimize their portfolios with respect to their relative prices, yields, riskiness and scarcity of preferred securities held. If, for instance, the yields of low-risk TS would fall, investors would demand lower 
risk premium in the segment of alternative investment assets, first in corporate bonds and later in nonfinancial assets. "This, in turn", as quoted in Friedman and Schwartz (1963), "tends to make existing nonfinancial assets expensive relative to newly constructed nonfinancial assets. At the same time, the general rise in the price level of nonfinancial assets tends to raise wealth relative to income, and to make the direct acquisition of current services cheaper relative to the purchase of sources of services. The monetary stimulus is, in this way, spread from the financial markets to the markets for goods and services", and ultimately affects the price level in the economy.

Simultaneously, the non-interest bearing credit balances of the Fed counterparties are on the rise and could be used for purchases of available investment assets, such as corporate bonds and equities, with higher relative yield / total returns. This spillover effect supports the prices of these assets and through higher demand boosts their prices and lowers their yields. That could lead to the easing of long-term credit conditions in the corporate bond segment, a positive effect on equities with spillover effect onto the real economy. Wealth effect associated with the increase in asset prices may also positively influence consumer consumption decisions - growth of consumer spending and an increase in investment activity of firms due to lowering the cost of financing by corporate bonds issuance could arise.

As for MBS purchases and TS with long duration, it is important to mention the market liquidity channel, when entrance of Fed in distorted or low liquidity market allows investors to trade assets without additional costs caused by low liquidity. Liquidity premium is reduced and investors more willingly hold these assets. The MBS market after the burst of property price bubble is one particular example of such a market. This and other possible channels of QE transmission are further introduced e.g. in Krishnamurthy and Vissing-Jorgensen (2011).

\section{3. $\mathrm{QE}$ related events}

Already in 2002 Bernanke in his speech ${ }^{5}$ referred to future possibility of QE in case of deflationary pressures and FFR close to zero and warned of negative effects of deflation on economy with reference to The Lost Decade in Japan. His remarks and speeches as the Fed Chairman in years 2006 - 2014 were always in the way of advocating QE and his voice was perceived by markets as an important

5 Bernanke speech (November 21, 2002) 
guideline of future unconventional measures, therefore, I include all important speeches regarding $\mathrm{QE}$ in the set of events.

The Fed initially announced purchases of $\$ 500$ billion of MBS and $\$ 100$ billion of agency bonds (AB) in Nov 2008. These purchases were at the beginning sterilized in SOMA holdings in this phase, so no contemporary increase in the Fed's balance sheet appeared until the approval of the Federal Open Market Committee (FOMC) in December. In his speech ${ }^{6}$, Bernanke outlined QE and later on the QE program was formally approved at the FOMC meeting on $16^{\text {th }}$ December. The program was extended in March 2009 for other purchases of $\$ 750$ billion in MBS and $\$ 100$ billion in $\mathrm{AB}$ and $\$ 300$ billion of TS in a time scope of the following six months. In August 2010, the Fed announced its intention to reinvest maturing MBS to TS and roll over maturing TS.

In his speech in August 2010, Bernanke mentioned the possibility of the second round of QE (QE2) as a valid option for monetary policy and stated that "the evidence suggests that the Fed's earlier program of purchases was effective in bring-

\section{Figure 1: Fed Balance Sheet}

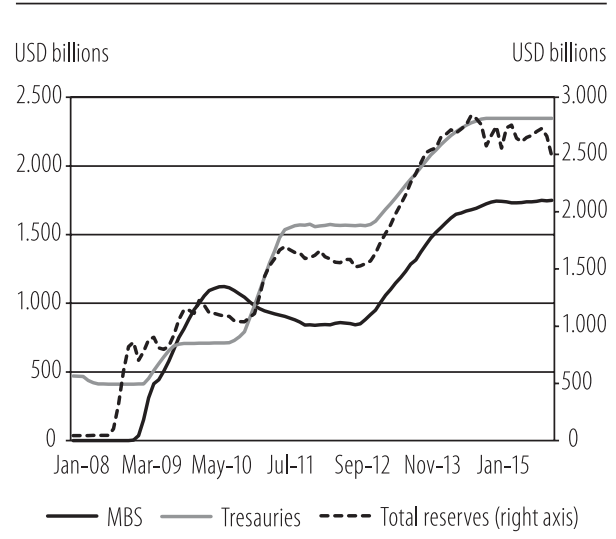

Source: Fed ing down term premiums and lowering the costs of borrowing in a number of private credit markets".7 At the following meetings, the FOMC confirmed its intention to keep SOMA holdings on the level of $\$ 2$ trillion and approved the second round of QE in November 2010 with approved purchases of $\$ 600$ billion of long-term TS (LTTS) at a pace of $\$ 75$ billion per month. During the consideration process of QE2, Bernanke argued with a series of academic studies that verified and quantified impact of QE1 e.g. D'Amico and King (2010), Gagnon et al. (2010) or Hamilton and $\mathrm{Wu}(2010)$ and their findings are presented further in next chapters.

\footnotetext{
6 Bernanke speech (December 1, 2008)

7 Bernanke speech (August 27, 2010)
} 
In September 2011, the FOMC decided to implement the Maturity Extension Program (MEP), also referred to as the Operation Twist $(\mathrm{OT})^{8}$, which represented duration changes in holdings of TS - $\$ 400$ billion of TS with duration of three years or less were meant to reinvest into TS with duration with range of six to thirty years till the end of 2012. MEP "should put downward pressure on longer-term interest rates and help make broader financial conditions more accommodative", without further increase of purchases or Fed's balance sheet. Reason was partially rooted in the fact that the Fed was criticized for monetization of federal debt and inducing the risk of future higher inflation above target, see for example open letter to Bernanke from a group of academics and financial market professionals from November 2010 where QE2 is opposed: "The planned asset purchases risk currency debasement and inflation..." Asset purchases in fact caused growth of NBR from $\$ 12$ billion in 2007 to ca. $\$ 2.4$ trillion at the end of 2013 (see Figure 1).

The third wave of QE - QE3 was introduced in September 2012, when the Fed announced its open-ended commitment to purchases MBS at a pace of $\$ 40$ billion per month and in December followed by purchases of LTTS at a pace of $\$ 45$ billion per month. Tapering was announced in Dec 2013 with further reductions of $\$ 10$ billion of cumulative monthly pace on each FOMC meeting. In Oct 2014 with the tapering finally ended the QE was technically concluded. All QE related events that possibly had impact on yields of purchased assets are in following table.

8 According to the original Operation Twist (1961) when the Fed intended to flatten treasury yields and strengthen dollar. More details are in Swanson (2011). 
Table 1: QE related events

\begin{tabular}{|c|c|c|c|c|}
\hline Date & & Event & Description & Scale \\
\hline 25-Nov-08 & \multirow{9}{*}{ 㫕 } & MPR & Purchases of the GSEs direct obligations and MBS. & $\begin{array}{l}+ \text { up to } \$ 100 \text { bill. } A B \\
+ \text { up to } \$ 500 \text { bill. } M B S\end{array}$ \\
\hline $1-$ Dec-08 & & BS & Fed could purchase L-T Treasury or agency securities. & \\
\hline 16-Dec-08 & & St. & Ready to expand its purchases and considers purchasing TS. & \\
\hline 28-Jan-09 & & St. & $\begin{array}{l}\text { Ready to expand purchases and the duration of the purchase } \\
\text { program and is prepared to purchase longer-term TS. }\end{array}$ & \\
\hline 18-Mar-09 & & St. & $\begin{array}{l}\text { FOMC announced a longer-dated Treasury purchase } \\
\text { program. }\end{array}$ & $\begin{array}{l}+\$ 750 \text { bill. MBS } \\
+\$ 100 \text { bill. AB } \\
+ \text { up to } \$ 300 \text { bill. LTTS }\end{array}$ \\
\hline 12-Aug-09 & & St. & $\begin{array}{l}\text { Total of announced amounts of TS will be purchased and } \\
\text { decided to gradually slow the pace of these purchases. }\end{array}$ & \\
\hline 23-Sep-09 & & St. & $\begin{array}{l}\text { Total of announced amounts of MBS and agency debt will be } \\
\text { purchased. Slows the pace of these purchases. }\end{array}$ & \\
\hline 4-Nov-09 & & St. & $\begin{array}{l}\text { Fed will purchase a total of } \$ 1.25 \text { trillion of MBS and } \$ 175 \text { bill. } \\
\text { of } A B \text { from announced maximum of } \$ 200 \text { billion. }\end{array}$ & $-\$ 25$ bill. $A B$ \\
\hline 10-Aug-10 & & St. & $\begin{array}{l}\text { Keep constant holdings of purchased securities by } \\
\text { reinvesting principal payments in LTTS and roll over maturing } \\
\text { TS. }\end{array}$ & \\
\hline 27-Aug-10 & \multirow{6}{*}{ జ̛ํ․ } & BS & $\begin{array}{l}\text { "Additional purchases of longer-term securities would be } \\
\text { effective in further easing financial conditions." }\end{array}$ & \\
\hline 21-Sep-10 & & St. & $\begin{array}{l}\text { FOMC maintain its existing policy of reinvesting principal } \\
\text { payments from its securities holdings. }\end{array}$ & \\
\hline $12-0 c t-10$ & & Min. & $\begin{array}{l}\text { FOMC members' sense that such accommodation (additional) } \\
\text { may be appropriate before long. }\end{array}$ & \\
\hline $15-O c t-10$ & & BS & $\begin{array}{l}\text { Program of securities purchases was successful, FOMC is } \\
\text { prepared to provide additional accommodation if needed. }\end{array}$ & \\
\hline $3-\mathrm{Nov}-10$ & & St. & Further purchases of LTTS ( $\$ 75$ billion per month) & $+\$ 600$ bill. LTTS \\
\hline 22-Jun-11 & & St. & $\begin{array}{l}\text { The Committee will complete its purchases of } \$ 600 \text { billion of } \\
\text { longer-term Treasury securities } \rightarrow \text { end of QE2 }\end{array}$ & \\
\hline 21-Sep-11 & \multirow[t]{2}{*}{$\stackrel{\stackrel{u}{\Sigma}}{.}$} & St. & $\begin{array}{l}\text { Purchase of } \$ 400 \text { billion of TS with remaining maturities of } \\
6-30 Y \text {, sell of TS with remaining maturities of 3Y or less. }\end{array}$ & $\begin{array}{l}+\$ 400 \text { bill. } 6 Y-30 Y \text { TS } \\
-\$ 400 \text { bill. } 1 Y-3 Y \text { TS }\end{array}$ \\
\hline $20-J u n-12$ & & St. & Fed continues to reinvest TS in MEP. & \\
\hline 22-Aug-12 & \multirow{12}{*}{$\stackrel{m}{\mathrm{O}}$} & Min. & $\begin{array}{l}\text { Many (FOMC) members judged that additional monetary } \\
\text { accommodation would likely be warranted fairly soon. }\end{array}$ & \\
\hline 13-Sep-12 & & St. & $\begin{array}{l}\text { Further purchases of MBS at a pace of } \$ 40 \text { bill. per month. } \\
\text { MEP and reinvesting principal payments still under way. }\end{array}$ & $\begin{array}{l}+\$ 40 \text { bill. in MBS } \\
\text { per month }\end{array}$ \\
\hline 12-Dec-12 & & St. & $\begin{array}{l}\text { Fed will purchase LTTS after MEP, initially at a pace of } \$ 45 \text { bill. } \\
\text { per month. }\end{array}$ & $\begin{array}{l}+\$ 45 \text { bill. of LTTS } \\
\text { per month }\end{array}$ \\
\hline 18-Sep-13 & & St. & $\begin{array}{l}\text { Committee decided to await more evidence that progress } \\
\text { will be sustained before adjusting the pace of its purchases. }\end{array}$ & \\
\hline 18-Dec-13 & & St. & \multirow{7}{*}{$\begin{array}{l}\text { FOMC decided to reduce the pace of its asset purchases by } \\
\$ 10 \text { billion per month. }\end{array}$} & \multirow{7}{*}{$\begin{array}{l}\text { - \$5(5) bill. in MBS(TS) } \\
\text { per month }\end{array}$} \\
\hline 29-Jan-14 & & St. & & \\
\hline 19-Mar-14 & & St. & & \\
\hline $30-A p r-14$ & & St. & & \\
\hline 18-Jun-14 & & St. & & \\
\hline $30-J u l-14$ & & St. & & \\
\hline 17-Sep-14 & & St. & & \\
\hline $29-0 c t-14$ & & St. & End of QE, holdings of L-T securities at sizable levels. & \\
\hline
\end{tabular}

Note: MPS stands for Monetary Policy Release, St. stands for FOMC statement, BS stands for Bernanke speech, Min. stands for FOMC minutes and MEP stands for Maturity Extension Program 


\section{Event study approach}

One of the few plausible methods to analyse impact of QE on market expectations is the event-study approach widely used in the analysis of initial impact of monetary policy announcements. Bernanke et al. (2004) used this approach to analyse the impact of the Fed's announcements on asset prices. Gagnon et al. (2010) used the same method to examine yield changes of US TS till March 2010. Joyce et al. (2011) and Christensen and Rudebusch (2012) used the event-study method to study the response of interest rates to QE in the UK and the U.S.A. Hausken and Ncube (2013) widely used the same method to study QE undertaken by Fed, ECB, BoE and BoJ. This study uses the event-study method on all crucial official announcements and chairman's speeches regarding the QE in US and extends the preceding studies that covered only initial parts of QE. Event study is used to capture immediate impact of events on yields of purchased assets when announcement itself can be fully reflected in short period around the time of announcements without the need to wait for real exercise of purchases. This could be achieved by transmission channels arising from the nature of communication itself such as a signal channel and partially other effects, e.g. a portfolio rebalancing channel or a liquidity channel of forward looking market participants that immediately reflects announcements in its expectations regarding future asset prices and the market liquidity and will in advance affect the markets without the Fed to even interfere. The announcement should be, of course, backed by a credible commitment and a timeline of purchases otherwise no such an effect would appear.

I use modified event study method based on OIS-TS spread presented in Joyce et al. (2011) when the change in yields induced by QE announcement can be split in two components and distinguished - the first one captures the change in future FFR expectations and the second one captures changes in term premium. OIS rate is a good proxy for the first component because of its ability to bear minimal counterparty credit and liquidity risks and fully reflects expectations of future FFR path. At maturity, both counterparties determine the net payment by the difference between the accrued interest of the fixed rate and the geometric averaging of the floating index rate on the notional swap principal. OIS have little credit risk exposure because there is no exchange of principal and at the maturity only the net difference in interest rates is being paid. Hull and White (2013) suggest that the OIS rate is the best proxy for risk-free rate currently available rather than LIBOR, in both situations, when portfolios are not collateralized and for collateralized portfolios as well. This assumption about OIS rates gives us a chance to use OIS-TS spread to quantify only the second component that reflects only changes caused by QE itself rather than future FFR expectations solely based 
on non-QE monetary policy. Joyce et al. (2011) consider also a liquidity channel at the time of announcement which is rather fearless assumption given the fact that at the time of announcement the Fed is not actually present in the market, therefore, this effect is considered to be weaker at the time of announcements and rather stronger during the actual exercise of purchases.

Formally, this relation of OIS-TS yield spread is characterized in the following way - equation (4.1) decomposes yield of TS into expected future short-term interest rates and term premium components:

$$
y(T S)_{t}^{n}=(1 / n) \sum_{i=0}^{n-1} E_{t} r_{t+1}+T P(T S)_{t}^{n}
$$

where $y(T S)_{t}^{n}$ is the yield on treasury security maturing after $n$-periods at time $t$, $r_{t+i}$ denotes one-period risk free interest rate while $T P(T S)_{t}^{n}$ denotes the $n$-period term premium associated with TS at time $t . T P(T S)_{t}^{n}$ can be further decomposed, see Hausken and Ncube (2013), into TP1(TS $)_{t}^{n}$ component, which captures instrument-specific effects that involve credit risk and imbalances caused by demand and supply interactions (e.g. Preferred Habitat-induced effects) and TP2 $(T S)_{t}^{n}$ component, which captures premiums determined by uncertainty regarding future interest rates within the maturity of TS:

$$
T P(T S)_{t}^{n}=T P 1(T S)_{t}^{n}+T P 2(T S)_{t}^{n}
$$

Under consideration of negligibility of credit risk premiums of US TS and an omission of the part of the liquidity premiums change in the immediate vicinity of the announcements, which is connected with exercise of purchases rather than announcements, the component $T P 1(T S)_{t}^{n}$ can be considered to reflect various effects of these announcements well. Change caused by the first or the second component would be marked $\triangle T P 1(T S)_{t}^{n}$ and $\triangle T P 2(T S)_{t}^{n}$ respectively.

Equation (4.3), which basically represents expectations about $\mathrm{o} / \mathrm{n}$ interest rates, and equation (4.4) together capture the OIS market in the same way as equations (4.1) and (4.2) capture the US Treasury market:

$$
y(O I S)_{t}^{n}=(1 / n) \sum_{i=0}^{n-1} E_{i} r_{t+1}+\operatorname{TP}(O I S)_{t}^{n}
$$

Equation (4.4) shows that term premium of OIS - TP $(O I S)_{t}^{n}$ can be decomposed in the same manner into $T P 1(O I S)_{t}^{n}$ component that captures instrument-specific premium and $T P 2(O I S)_{t}^{n}$ component that captures premiums determined by uncertainty regarding future interest rates within the maturity of OIS: 


$$
T P(O I S)_{t}^{n}=T P 1(O I S)_{t}^{n}+T P 2(O I S)_{t}^{n}
$$

Change caused by the first or the second component would be marked $\triangle T P 1(O I S)_{t}^{n}$ and $\triangle T P 2(O I S)_{t}^{n}$ respectively. If the reasonable assumption that negligibility of component $T P 1(O I S)_{t}^{n}$ that captures liquidity and credit risk premiums and effects of demand and supply interactions in IOS is correct due to very liquid OIS market and virtually non-existing credit risk threat (see Hull and White, 2013), we can consider remaining component $T P 2(O I S)_{t}^{n}$ to be affected equally by expected future short-term interest rate as component $T P 2(T S)_{t}^{n}$ as it is captured in equation (4.5). ${ }^{9}$ Therefore, a change caused by $\mathrm{QE}$ announcements would cause the same change in $T P 1(T S)_{t}^{n}$ as in $T P 1(O I S)_{t}^{n}$ - changes are expressed by $\triangle T P 1(T S)_{t}^{n}$ and $\triangle T P 1(O I S)_{t}^{n}$.

$$
\Delta T P(O I S)_{t}^{n}=\Delta T P 2(O I S)_{t}^{n}=\Delta T P 2(T S)_{t}^{n}
$$

Thus the spread in yield changes between OIS and TS stated in equation (4.6) gives us the size of the instrument-specific effect, which includes credit risk and imbalances caused by demand and supply interactions in TS market caused by $\mathrm{QE}$ announcements.

$$
\Delta y(T S)_{t}^{n}-\Delta y(O I S)_{t}^{n}=\Delta T P 1(T S)_{t}^{n}
$$

Existing event-study studies emphasized correct "fairly narrow interval" of the event window to capture the most of the reaction and not to include other unrelated effects. Krishnamurthy and Vissing-Jorgensen (2011) used two-day window claiming that one-day window would be enough only for TS with shorter maturities due to higher market liquidity. Joyce et al. (2011) in their study of QE in the UK and Hausken and Ncube (2013) chose two-day window as well and rejected one and three-day window. Gagnon et al. (2011) and Christensen and Rudebusch (2012) on the other hand chose one-day window. This study follows the majority and uses the two-day window on its event study analysis and originally applies this method using OIS-TS yield spread changes on QE in US and unlike the majority of existing studies examines the whole QE in years 2008 - 2014 including events of 2013 and 2014 tapering and not only part of it.

9 The meaningfulness of this reasoning is inseparably connected with consideration regarding OIS - they are ordinarily used as a hedging against unexpected future changes in overnight LIBOR rates and its maturity is fixed for that purposes to $\mathrm{n}$ periods to satisfy hedger funding needs. 
Assumptions regarding this event-study can be summarized as follows:

- Official events that are included had exclusive impact on the creation of expectations regarding QE of economic agents in the markets concerned.

- Event window is chosen correctly in the way that results are influenced by other external factors in lowest possible way and instrument-specific shocks in the event windows are negligible.

- Markets are effective in a way that they are capable of absorbing the most of information about future asset purchases already in time of announcements rather than during the implementation. ${ }^{10}$

All QE directly affected assets classes are present - TS are represented by constant maturity US TS with maturities 2, 3, 5, 10 and 30 years $^{11}$, MBS represented by Ginnie Mae and Fannie Mae MBS indices and an agency debt represented by Fannie Mae and Freddie Mac indices. ${ }^{12}$ For comparative purposes I include Moody's seasoned corporate bonds Aaa and Baa indices. ${ }^{13}$ Yields changes of all these assets are adjusted for OIS rate changes with corresponding duration. Twoday window instrument-specific yield changes in basis points of analysed actives are captured in following table:

\footnotetext{
${ }^{10}$ Realistic assumption is to consider adaptive market hypothesis proposed by Lo (2004). Lo suggests that "If multiple species (or the members of a single highly populous species) are competing for rather scarce resources within a single market, that market is likely to be highly efficient, e.g. the market for 10-Year US Treasury Notes, which reflects most relevant information very quickly indeed."Since this paper deals mainly with US Treasury market, it seems appropriate to assume validity of adaptive market hypothesis.

${ }^{11}$ Treasury Inflation Protected Securities (TIPS) are not involved due to their low importance (ca. $7 \%$ of total Treasury issued debt securities - Monthly Statement of the Public Debt).

${ }^{12}$ All indices used are constructed and provided by Merrill Lynch.

${ }^{13}$ Used as index of the performance of all bonds with Aaa/Baa rating by Moody's Investors Service.
} 
Table 2: Assets yields changes

\begin{tabular}{|c|c|c|c|c|c|c|c|c|c|c|c|c|c|c|}
\hline \multirow{2}{*}{ Date } & \multirow{2}{*}{\multicolumn{2}{|c|}{ Event }} & \multicolumn{6}{|c|}{ Treasury } & \multicolumn{2}{|c|}{ MBS } & \multicolumn{2}{|c|}{ Agency debt } & \multirow{2}{*}{ Aaa } & \multirow{2}{*}{ Baa } \\
\hline & & & $1 Y$ & $2 Y$ & $3 Y$ & $5 Y$ & $10 \mathrm{Y}$ & $30 Y$ & GM & FaM & FaM & FrM & & \\
\hline $25-N o v-08$ & \multirow{9}{*}{$\overline{\mathrm{O}}$} & MPR & 3 & -10 & 4 & 2 & -14 & -2 & -44 & -46 & -32 & -28 & 2 & 6 \\
\hline 1-Dec-08 & & $\mathrm{BS}$ & -4 & 8 & 8 & 3 & -35 & -37 & 18 & 4 & -6 & -7 & -38 & -34 \\
\hline 16-Dec-08 & & St. & 4 & 5 & 7 & 6 & -15 & -14 & -60 & -57 & -24 & -23 & -17 & -23 \\
\hline 28-Jan-09 & & St. & 0 & -5 & -2 & 1 & 43 & 46 & 49 & 31 & 1 & -1 & 42 & 37 \\
\hline 18-Mar-09 & & St. & -7 & -11 & -12 & -17 & -26 & -6 & -84 & -83 & -19 & -21 & -5 & -2 \\
\hline 12-Aug-09 & & St. & 1 & -1 & -1 & 4 & -6 & 6 & 6 & 6 & 0 & -3 & 4 & 5 \\
\hline 23-Sep-09 & & St. & 0 & 0 & 2 & 3 & 9 & 12 & 2 & 3 & 5 & 3 & 12 & 11 \\
\hline 4-Nov-09 & & St. & 2 & 4 & 3 & 1 & -4 & -4 & -3 & -3 & 9 & 8 & -2 & -5 \\
\hline 10-Aug-10 & & St. & -1 & 3 & 2 & 0 & -15 & -9 & -14 & -15 & 1 & 2 & -10 & -7 \\
\hline 27-Aug-10 & \multirow{6}{*}{ 뻐 } & BS & 1 & -2 & -4 & -4 & 2 & 5 & 0 & 4 & -4 & -4 & 8 & 6 \\
\hline 21-Sep-10 & & St. & 0 & 0 & 1 & -1 & -27 & -24 & -8 & -29 & -1 & -1 & -21 & -24 \\
\hline $12-$ Oct- 10 & & Min. & 1 & 3 & 4 & 3 & 13 & 17 & 2 & 5 & 3 & 3 & 16 & 14 \\
\hline $15-0 c t-10$ & & BS & 1 & 0 & -2 & 1 & -2 & 0 & 9 & 9 & -3 & -2 & 0 & 1 \\
\hline 3-Nov-10 & & St. & -1 & 1 & 0 & -2 & 2 & 23 & -8 & -5 & 0 & 1 & 21 & 18 \\
\hline 22-Jun-11 & & St. & -1 & 0 & 0 & -2 & -10 & -8 & -4 & -4 & 1 & 1 & -10 & -9 \\
\hline 21-Sep-11 & \multirow{2}{*}{ 㞻 } & St. & -2 & -1 & 4 & 4 & -11 & -30 & -38 & -69 & -1 & 1 & -9 & -14 \\
\hline 20 -Jun-12 & & St. & 0 & 0 & -1 & -1 & -1 & -2 & 1 & 0 & -2 & -2 & -6 & -7 \\
\hline 22-Aug-12 & \multirow{12}{*}{ 㟧 } & Min. & 0 & -2 & -2 & -1 & -1 & -1 & -26 & -29 & -2 & -2 & -3 & -4 \\
\hline 13-Sep-12 & & St. & -1 & 2 & 2 & 1 & 5 & 3 & -32 & -41 & 2 & 1 & 5 & 2 \\
\hline $12-$ Dec- 12 & & St. & -2 & 2 & -1 & 0 & 1 & 2 & 2 & 14 & 1 & 0 & 0 & -2 \\
\hline 18-Sep-13 & & St. & -1 & -2 & -2 & -2 & -1 & 0 & -11 & -7 & -2 & 0 & 4 & 4 \\
\hline 18-Dec-13 & & St. & -3 & -2 & -2 & 1 & -2 & -6 & -4 & -1 & -1 & -2 & -17 & -10 \\
\hline 29-Jan-14 & & St. & 0 & 0 & 0 & 0 & 0 & 1 & -2 & -1 & 0 & 0 & 1 & 1 \\
\hline 19-Mar-14 & & St. & -1 & 1 & 1 & 1 & 0 & -1 & -7 & -5 & -2 & -4 & -8 & -8 \\
\hline 30-Apr-14 & & St. & -1 & -1 & -2 & -2 & -2 & 0 & -7 & -5 & 4 & 1 & -2 & -3 \\
\hline 18-Jun-14 & & St. & -1 & 1 & -1 & -1 & 1 & 1 & -4 & -3 & -1 & 2 & 4 & 3 \\
\hline 30-Jul-14 & & St. & 0 & -2 & -1 & 0 & 1 & 0 & 7 & 8 & 5 & 6 & -1 & 0 \\
\hline 17-Sep-14 & & St. & -2 & 0 & 0 & 1 & 2 & 1 & -4 & -4 & -4 & -2 & -1 & 0 \\
\hline $29-0 c t-14$ & & St. & -2 & 1 & 1 & 0 & 0 & -2 & -4 & -3 & 0 & 0 & -10 & -4 \\
\hline \multicolumn{3}{|c|}{ Total } & -15 & -9 & 7 & -1 & -94 & -30 & -269 & -326 & -72 & -73 & -42 & -49 \\
\hline \multicolumn{3}{|c|}{ QE1 } & -2 & -8 & 11 & 3 & -64 & -8 & -131 & -160 & -65 & -70 & -12 & -13 \\
\hline \multicolumn{3}{|c|}{ QE2 } & 1 & 3 & -2 & -4 & -22 & 13 & -10 & -20 & -3 & -2 & 14 & 6 \\
\hline \multicolumn{3}{|c|}{ MEP } & -2 & -1 & 4 & 4 & -11 & -30 & -38 & -69 & -1 & 1 & -9 & -14 \\
\hline \multicolumn{3}{|c|}{ QE3 } & -12 & -3 & -5 & -2 & 4 & -2 & -91 & -77 & 0 & 0 & -28 & -21 \\
\hline \multicolumn{3}{|c|}{ SD events } & 2 & 5 & 7 & 10 & 11 & 9 & 21 & 22 & 9 & 9 & 9 & 9 \\
\hline \multicolumn{3}{|c|}{ SD all } & 1 & 3 & 4 & 6 & 6 & 6 & 10 & 10 & 5 & 5 & 6 & 6 \\
\hline
\end{tabular}

Note: GM stands for Ginnie Mae (The Government National Mortgage Association), FaM stands for Fannie Mae (The Federal National Mortgage Association) , FrM stands for Freddie Mac (The Federal Home Loan Mortgage Corporation)

Cumulative changes in yields represent the overall effect of QE news explicitly published in announcements and speeches. The biggest impact is noticeable in 
MBS where announcements severely affected this market. The drop of yields in MBS around $300 \mathrm{bp}$, around $150 \mathrm{bp}$ in QE1, can be accounted not only to signalling and portfolio-balancing effects but, in contrast to TS, also to improvements of market functionality caused by the Fed participation - Hancock and Passmore (2011), for instance, mention a clearer government backing of MBS market. MBS market was paralyzed for a long time after a burst of property price bubble and this did not improve until the Fed embarked on this market. Cumulative yield change in TS segment is the most noticeable at 10Y, and not surprisingly, exactly in this segment the Fed realized most of its purchase. A noticeable decrease in yield of $30 \mathrm{bp}$ is present in 30Y, especially at a time of MEP when Fed announced its intention to buy rather TS with longer maturities. Important finding confirming assumption is a presence of the biggest effect in initial phases of QE when market subjects had no exact idea of the consequences of QE, fairly unconventional measure at that time. A key finding is the fact that a large difference in changes of the yields of $10 \mathrm{Y}$ and short TS (2Y and $3 \mathrm{Y}$ ) in turn means that the change was caused mainly due to a reduction of term premiums rather than explicit commitment to hold FFR low for "extended period" of time as mentioned in FOMC statements concerning the policy rate guidance. Changes in yield of Moody's seasoned corporate bonds Aaa and Baa indices suggest that the Fed actions had overflowing effect on other financial markets in a way which is in line with the portfolio balance hypothesis.

Studies that examine this theme using various methods found out that purchases undertaken by Fed had some effect on yields of TS - as for 10Y TS during QE1 the drop of yield is in the range from 13 bp according to Hamilton and Wu (2010), through $39 \mathrm{bp}$ according to Doh \& Taeyoung (2010), $45 \mathrm{bp}$ according to D'Amico and King (2010), $60 \mathrm{bp}$ according to Mayer (2010), $91 \mathrm{bp}$ according to Gagnon et al. (2010) and to 107 bp according to Neely (2011). This study, with the method used, falls by its results of $64 \mathrm{bp}$ in the yield drop of US Treasury 10Y in QE1 somewhere in the middle as for the strength of quantified effect. In comparison with the conventional monetary policy, the reduction of TS yields with remaining maturity $10-15 \mathrm{Y}$ about 50 bs would be equivalent to $200 \mathrm{bp}$ reduction in FFR, as Meaning and Zhu (2011) claim.

For QE2 events the impact was 22 bp, in D'Amico and King (2010) a Krishnamurthy, Vissing-Jorgensen (2011) it is 55 bp and 33 bp respectively. MEP caused change of $11 \mathrm{bp}$, Swanson (2011) came with $15 \mathrm{bp}$. QE3 brought no clear effect in segment of TS, only in MBS and corporate bonds. That is probably the consequence of the fact that QE3 involves tapering process and the fact that market participants were broadly familiar with QE in that time. 
Figure 2 depicts cumulative changes in yields across markets from the initial announcement in November 2008 to the end of asset purchases in October 2014. It is obvious that yields fell greatly during that period and changes induced by the Fed purchases can be accounted only for a part of it, especially in TS markets with longer maturities and the MBS market. A significant impact is also visible in the agency debt and corporate Aaa and Baa debt markets, but only as a contributor to the overall impact, which was visibly influenced by other factors. That was the Fed's intention, after all, to affect the long end of yield curve and sup-

Figure 2: Cumulative changes in yields

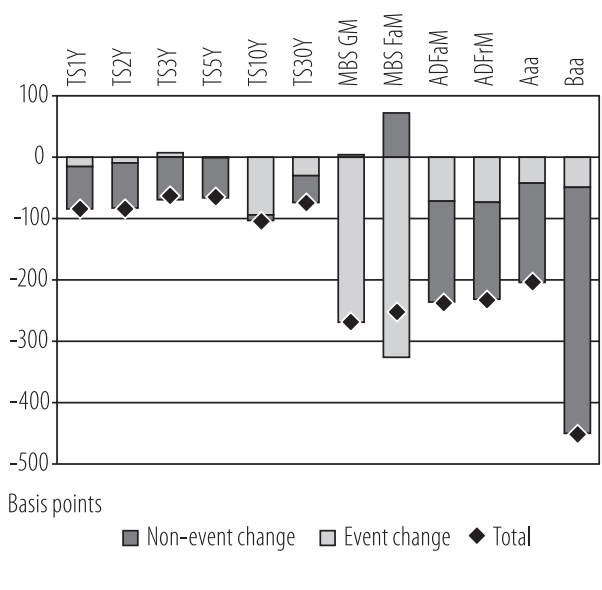

Source: own calculations port investments of individuals and companies. The rest of yields decline in these markets can be accounted to lower expectations of future FFR and improve conditions on financial markets with regaining trust and lowering risk premiums. What is also important to mention is a possible effect of the European debt crisis approximately in years 2010 to 2012 when sovereign bonds in the EMU were under the pressure and the US and UK bond markets acted as a safe haven as mentioned in Stracca (2013). Therefore, there was possibly upward pressure on both sovereign and corporate bond prices that could further enhance full potency of asset purchases in US, which would be consistent with findings of this paper. It is visible especially in the market for corporate bonds where QE-related effects are accountable only for a part of yield decrease overall. Equity markets were also possibly affected in the opposite direction by the European debt crisis, especially with downward pressures on excess returns in the financial sector.

Weak point of the event-study approach is the fact that there can still be other effects captured in two-day event window and that movements in the prices of analysed instruments during the event window could be partially caused by instrument-specific events and shocks. Therefore, I apply VAR-IRF modelling in the following chapter to find out the impact and the persistence of large scale asset purchases of the Fed in a different manner. 


\section{Impulse-response analysis}

To determine possible relations and impacts across the time of series of yields of purchased assets classes and QE series that capture the strength of QE announcements, I use two structural vector autoregressive models (SVARs) in this section. Due to the fact that it is difficult to describe relations amongst all variables in easy not-restrictive way without imposing heavily binding assumptions of the model and that a priori determination of exogeneity, or rather endogeneity is also questionable. Hence I use VARs in this section that allow me to approach to all variables as endogenous and extension for impulse response functions (IRFs) since they can give us the information about the size and persistency of impact of the shock in one variable on the other. IRFs measure the effects of one SD shock induced by one endogenous variable to another endogenous variable.

All components of both SVARs are stationary - first differences of data series were used for all non-stationary data series. As for the appropriate lag lengths, the Hannan-Quinn information criterion (HQIC) and the Akaike information criterion (AIC) were applied and VARs were subsequently constructed as VAR(5) and $\operatorname{VAR}(6)$. In $\operatorname{VAR}(5)$ there are eight and in $\operatorname{VAR}(6)$ there are six variables marked from $y_{1 \mathrm{t}}$ to $\mathrm{y}_{8 \mathrm{t}}$ and $\mathrm{y}_{1 \mathrm{t}}$ to $\mathrm{y}_{6 \mathrm{t}}$, respectively, where current values of variables depend on a specific combination of previous $k$ values of all variables and error terms. Constructed VAR(5) in general form can be written as:

$$
\left(\begin{array}{c}
y_{1 t} \\
\vdots \\
y_{8 t}
\end{array}\right)=\left(\begin{array}{c}
\alpha_{10} \\
\vdots \\
\alpha_{80}
\end{array}\right)+\left(\begin{array}{ccc}
\beta_{11} & \cdots & \beta_{18} \\
\vdots & \ddots & \vdots \\
\beta_{81} & \cdots & \beta_{88}
\end{array}\right)\left(\begin{array}{c}
y_{1 t-1} \\
\vdots \\
y_{8 t-1}
\end{array}\right)+\cdots+\left(\begin{array}{ccc}
\phi_{11} & \ldots & \phi_{18} \\
\vdots & \ddots & \vdots \\
\phi_{81} & \cdots & \phi_{88}
\end{array}\right)\left(\begin{array}{c}
y_{1 t-5} \\
\vdots \\
y_{8 t-5}
\end{array}\right)+\left(\begin{array}{c}
u_{1 t} \\
\vdots \\
u_{8 t}
\end{array}\right)
$$

where $u_{i t}$ is a white noise disturbance with $\mathrm{E}\left(u_{i t}\right)=0,(\mathrm{i}=1, . ., 8)$ and $\mathrm{E}\left(u_{i t}\right)=0$, $\mathrm{E}\left(u_{1 t} \ldots u_{8 t}\right)=0$ and $k=5$ in case of $\operatorname{VAR}(5)$. The second estimated VAR - VAR(6) is assumed accordingly in the same manner with $k=6$. Stability of VARs was tested for a unit root where the unit root was ruled out with Augmented DickeyFuller test (ADF). For calculating the IRFs, the correct ordering of the variables is important because IRs refer to a unit shock to the errors of only one equation, other equations error terms in the VAR are being held constant. Orthogonalised impulse responses are generated for variables according to the explicit ordering to avoid issues stemming from the fact that error terms are likely to be correlated in the VAR. Therefore, Cholesky adjusted ordering was used in both VARs to avoid this possibility. 
VAR(5) captures relations between QE announcements expressed by the total amount of announced purchases - SOMA holdings of TS, MBS and AD, yield changes of the very same assets purchased by the Fed and the OIS rate of corresponding maturity. VAR(6) captures relations between yield changes of purchased assets, the OIS of relevant maturity, and other assets that are being considered to be an investment alternative for portfolio-balancing decision taking investors such as corporate bond yields and total return of equity index Russell 3000. Both VARs were estimated several times with a different structure of maturities of involved variables according to the structure of purchased assets and only the most representative ones were chosen in following IRF discussion. Granger Causality test indicates strong evidence of lead-lag interactions between the series of VAR(5) where the yields of TS (TR10Y), MBS (MBS) and agency debt $(A B)$ show causality at the 5\% significance to series that captures QE announcement $(Q E)$. For VAR(6) test indicates evidence of causality from the yield of treasury securities with remaining maturity 10+ years (TR10Y) to commercial bonds yields with remaining maturity $10+$ years $(C 10 Y)$ and the total return series of Russell 3000 index (R3000) that represents US equity market at the 10\% significance level. On the contrary, Granger Causality test did not show causality from $R 3000$ and C10Y to MBS yields.

Obtained IRFs for constructed VAR(5) are as follows: ${ }^{14}$

Figure 3: Response of MBS yield

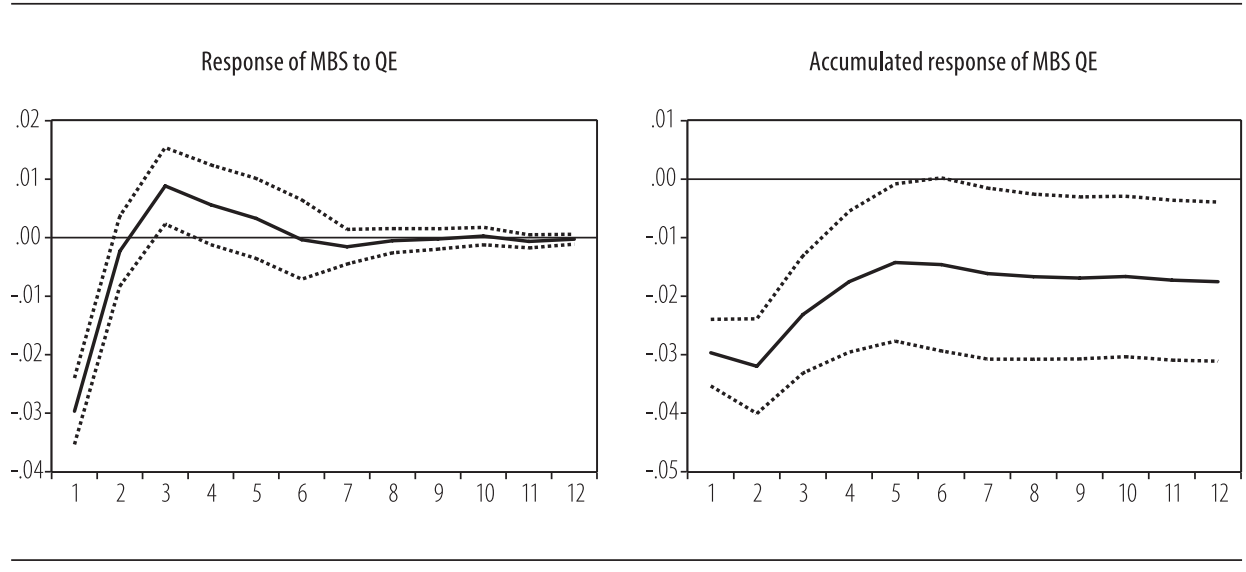

${ }^{14}$ Responses / accumulated responses to Cholesky one S.D. Innovations \pm 2 S.E. 
The responses of TS, MBS and AD yields to the shocks in QE announcements derived from VAR(5) are short-lived and disappear within few days, which is caused by high efficiency of TS market. ${ }^{15}$ IRF and accumulated IRF of MBS yield is presented above as representative for all assets purchased because IRFs are more or less the same in shape for all involved asset classes. It is clear from these responses that announcements had some measurable effect on MBS yields - one SD shock in series $Q E$ (39.4) has the initial impact around 3 bp which means that in the case of $25^{\text {th }}$ of November 2008 it could induce yield shift of $45 \mathrm{bp}$ for MBS. For TS and AD it is $1.3 \mathrm{bp}$ and $1 \mathrm{bp}$, respectively, which would mean ca. $20 \mathrm{bp}$ and $15 \mathrm{bp}$, respectively, as of $25^{\text {th }}$ of November 2008 QE announcement. As for SOMA holdings, the IRFs did not show any clear effect which is probably caused by weekly Fed provided data frequency that is not high enough to supply all other variables with daily frequency and by the fact that the amount of US Treasury backed federal debt securities grew faster than before and therefore the Fed purchases of TS could be partially offset. An important finding, that is in line with assumptions stated in the previous chapter, is the fact that OIS IRFs provide no unambiguous evidence of $\mathrm{QE}$ announcement impact on these rates that represent benchmark for credit risk-free IRs in the economy. Possible explanation is that signalling channel of future accommodative monetary policy that arises from QE announcements did not play strong role in days of announcement. Future accommodative monetary policy was apparently communicated well enough before the beginning of QE and was already well reflected in OIS. This strengthens assumption about greater importance of the effects such as the portfolio-balance effect in yield changes during the event study two-day window, mentioned in the previous chapter, and reduces possible impact of component, which captures premiums determined by uncertainty regarding future interest rates within the maturity of OIS and consequently TS.

Obtained IRFs for constructed VAR(6) are as follows:

${ }^{15}$ US Treasury backed debt securities market is the most liquid sovereign bond market especially in the segment of 10 year maturity. E.g. daily average volume traded on CME $10 \mathrm{Y}$ on the run futures is ca. 800 thousand lots. 
Figure 4: Responses of alternative assets yields
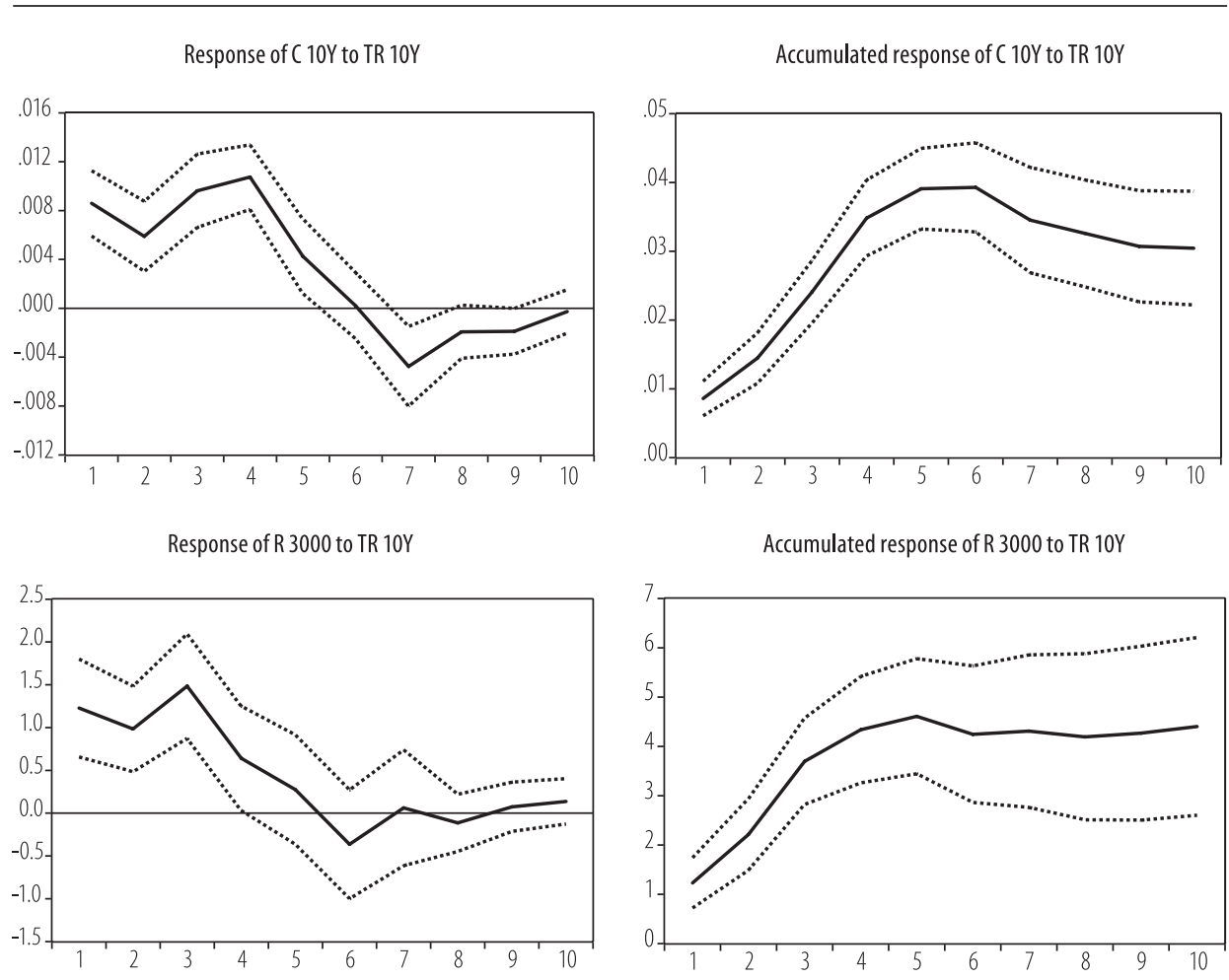

IRFs and accumulated IRFs of 10Y corporate bond yield (C10Y) and Russell 3000 total return index (R3000) are presented above - there is virtually no response as for both to the one SD shocks in QE announcements derived from VAR(6). That would suggest that announcements of QE had no direct effect on alternative assets in portfolio-balance framework and that the imminent signalling effect is absent and the whole pressure on yields of these assets was induced entirely through TS yields, as it is observable in IRFs of C10Y and R3000 to one SD shock in TR10Y. One SD shock in series TR10Y (0.063) has initial impact around $1 \mathrm{bp}$ which means that in the case of Bernanke speech of $1^{\text {st }}$ of December 2008 it could induce yield shift of $5.6 \mathrm{bp}$ for C10Y. For R3000 it is 1.3 index points which would mean ca. 7.2 ip as of $1^{\text {st }}$ of December 2008. The effect of one SD deviation shock in $\mathrm{QE}$ announcement series disappeared within six days in both cases.

All IRFs show some evidence of the impact of examined QE events that are in line with model assumptions. Treasury yields are affected by these events and 
this effect quickly fades off, as one would expect in highly efficient TS market. Alternative assets yields are affected through change in TS yield, which speaks in favour of portfolio-balance channel. Signalling and other channels of transmission could also be present, but their identification and the separation of one from another is rather complicated and can be only assumed within limited boundaries of the model used.

\section{Conclusions}

Event study and SVAR analysis undertaken in this study revealed significant impact of the Fed announcements concerning the QE on US treasury yields and an intermediary impact of these changes on other assets in the economy, namely corporate bonds and equity indexes represented by Russell 3000 total return index. The Fed virtually overcame limitations of its conventional monetary policy and used this unconventional measure to further ease credit conditions in the economy beyond the standard framework. Event study shows different impact of particular announcements on TS, MBS and AB yields in different phases of the QE program - calming effect of the Fed interventions on MBS market in early stages of the program and shifting of the effect on TS with longer maturities during the MEP is clearly observable. Tapering announcements of the QE meant no surprise for market participants and these announcements were apparently highly expected. Following VAR model and IRFs show intermediated QE impact on other yields in the economy and its persistency - this shows some indirect evidence of portfolio-balance effect, but the possible role and strength of various transmission channels is unclear due to the nature of the model and its limited ability to uncover these relations. 


\section{References}

1. Andrés, López-Salido \& Nelson. 2004. “Tobin’s Imperfect Asset Substitution in Optimizing General Equilibrium”. Journal of Money, Credit, and Banking, 36 (4): 665-90.

2. Bernanke, B. (2002). "Deflation: Making Sure "It" Doesn't Happen Here". Speech at the National Economists Club, Washington, D.C., November 21

3. Bernanke, B. (2008). "Federal Reserve Policies in the Financial Crisis". Lecture At the Greater Austin Chamber of Commerce, Austin, Texas, December 1

4. Bernanke, B. (2010). “The Economic Outlook and Monetary Policy”. Speech at the Federal Reserve Bank of Kansas City Economic Symposium, Jackson Hole, Wyoming, August 27

5. Bernanke, Reinhart \& Sack. (2004). "Monetary Policy Alternatives at the Zero Bound: An Empirical Assessment”. Divisions of Research \& Statistics and Monetary Affairs Federal Reserve Board Washington, D.C. Finance and Economics Discussion Series No. 48

6. Brunner, K. and Meltzer, A. (1973). "Mr. Hicks and the 'Monetarists"”. Economica 40 (157): 44-59

7. Christensen \& Rudebusch. (2012). “The Response of Interest Rates to U.S. and U.K. Quantitative Easing”. Federal Reserve Bank of San Francisco. Working Paper Series, 2012-06

8. Clouse, Dale, Athanasios, Small \& Tinsley. (2003). "Monetary Policy when the Nominal Short-Term Interest Rate is Zero". Berkeley Electronic Press. Topics in Macroeconomics, No. 3(1), Article 12

9. D’Amico, S. King, T. (2010). "Flow and Stock Effects of Large-Scale Treasury Purchases". Finance and Economics Discussion Series Divisions of Research \& Statistics and Monetary Affairs Federal Reserve Board, Washington, D.C.

10. Doh \& Taeyoung. (2010). “The Efficacy of Large-Scale Asset Purchases at the Zero Lower Bound”. Federal Reserve Bank of Kansas City

11. Eggertsson, G. \& Woodford, M. (2003). “The Zero Bound on Interest Rates and Optimal Monetary Policy". Brookings Papers on Economic Activity, No. 1, p. 139-233

12. Friedman, M. and Schwartz, A. (1963). "A Monetary History of the United States 1867 - 1960". Princeton University Press

13. Gagnon, J., Raskin, M., Remache, J. \& Sack, B. (2010). "Large-Scale Asset Purchases by the Federal Reserve: Did They Work?”. Federal Reserve Bank of NY Staff Reports, No. 441, March 
14. Gagnon, J., Raskin, M., Remache, J. \& Sack, B. (2011). “The Financial Market Effects of the Federal Reserve's Large-Scale Asset Purchases”. Peterson Institute for International Economics

15. Hamilton, J. \& Wu, J. (2011). “The Effectiveness of Alternative Monetary Policy Tools in a Zero Lower Bound Environment”. National Bureau of Economic Research (NBER). Working Paper No. 16956

16. Hancock, D. \& Passmore, W. (2011). “Did the Federal Reserve's MBS Purchase Program Lower Mortgage Rates?". Finance and Economics Discussion Series. Divisions of Research \& Statistics and Monetary Affairs Federal Reserve Board, Washington, D.C.

17. Hausken, K \& Ncube, M. (2013). "Quantitative Easing and Its Impact in the US, Japan, the UK and Europe". Springer - New York

18. Hull, J. \& White, A. (2013). "LIBOR vs. OIS - The Derivatives Discounting Dilemma”. Journal of Investment Management, Vol. 11, No. 3, p. 14-27

19. Joyce, Lasaosa, Stevens \& Tong. (2011). “The Financial Market Impact of Quantitative Easing in the United Kingdom”. Bank of England, Working Paper No. 393

20. Klyuev, V., Imus, P. \& Srinivasan, K. (2009). "Unconventional Choices for Unconventional Times: Credit and Quantitative Easing in Advanced Economies". IMF Staff Position Note, November 4

21. Krishnamurthy, A. \& Vissing-Jorgensen, A. (2011). “The Effects of Quantitative Easing on interest rates: Channels and implications for policy". National Bureau of Economic Research (NBER). Working Paper No. 17555

22. Lo, A. (2004). “The Adaptive Markets Hypothesis: Market Efficiency from an Evolutionary Perspective”. Journal of Portfolio Management. Vol. 30, No. 5 , p. $15-29$

23. Mayer, L. (2010) "Some Empirical Evidence on the Effectiveness of Monetary Policy at the Zero Bound". Federal Reserve Bank of Boston 55th Economic Conference

24. Meaning, J. \& Zhu, F. (2011). “The impact of recent central bank asset purchase programmes”. BIS Quarterly Review, December 2011

25. Mishkin, F. (2011). "Monetary Policy Strategy - Lessons from the Crisis". National Bureau of Economic Research (NBER). Working Paper No. 16755

26. Neely, J. (2011). “The Large-Scale Asset Purchases Had Large International Effects”. Federal Reserve Bank of St. Louis. Working Paper 2010-018C

27. Stracca, L. (2013). “The global effects of the euro debt crisis". ECB Working Paper Series, No. 1573, August 2013

28. Swanson, E. (2011). "Let's Twist Again A High-Frequency Event-Study Analysis of Operation Twist and Its Implications for QE2”. Federal Reserve Bank of San Francisco 
29. Tobin, J. (1969). "A General Equilibrium Approach to Monetary Theory". Journal of Money, Credit, and Banking 1 (1): 15-29

30. Vayanos, D. Vila, J. (2009). "A Preferred Habitat Model of the Term Structure of Interest Rates". National Bureau of Economic Research (NBER), Working Paper No. 15487

31. Yates, A. (2003). "Monetary policy and the zero bound to nominal interest rates". Bank of England Quarterly Bulletin, Spring 2003, p. 27-37 